\title{
PCBP1 wt Allele
}

National Cancer Institute

\section{Source}

National Cancer Institute. PCBP1 wt Allele. NCI Thesaurus. Code C95866.

Human PCBP1 wild-type allele is located within 2p13-p12 and is approximately $2 \mathrm{~kb}$ in length. This allele, which encodes poly(rC)-binding protein 1 , is involved in the regulation of mRNA splicing. 